\title{
Humanitarian news frame in Harian Republika and Kompas on Wamena ferugees (framing analysis on Republika news and Kompas edition 24 - 30 September 2019 on the tragedy of the riots in Wamena)
}

\author{
Ghafur Sitohan ${ }^{\mathrm{a}, 1, *}$ \\ ${ }^{a}$ Muhammadiyah University of Yogyakarta \\ 1 gsitohan08@gmail.com* \\ * corresponding author
}

Article history

Received 06-01-2021

Revised 18-01-2021

Accepted 02-02-2021

Keywords

Contructivism

Frame of News

Framing

Tragedy of Wamena Riot

\begin{abstract}
Conflict against the backdrop of the dissemination of hoaks information, accompanied by elements of racism repeated and targeted papuans. In 2019 , a riot led to an alleged racist slur by a teacher, to his student on September 18, 2019. The unrest resulted in various humanitarian problems, such as civilian casualties and destruction of public facilities. As a result, a wave of problems related to the exodus of citizens continues to come. This research aims to discuss the news frame of two media, namely Republika Daily and Kompas with discussion of the Tragedy of Riots in Wamena City, Papua Province (September 24, 2019 - September 30, 2019). Meanwhile, the concept of a crisis of manness and responsibility to protect both media, agreed to package it in the same point of view. The frame of republika and kompas daily news in the concept of humanitarian crisis is classified in the complex emergencies category, and the facts presented about the role of the Government in accordance with the concept of responsibility to protect.
\end{abstract}

This is an open access article under the CC-BY-SA license.

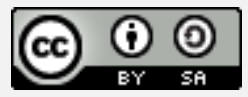

\section{Introduction}

Media has an important role in the present era, obliged to convey information as public consumption. Republika daily newspaper and Kompas are two national media that have the characteristic of various interests, such as the economy, and different ideologies. The events presented by the media are the result of selection, where important events will be newsworthy (Prihandini, 2018).

The news frame formed by Republika Daily and Kompas is based on religious aspects, the establishment of a government setting, and a strong mission vision. In other words, the constructionist views of the two media are interesting to discuss at the news of the tragedy of the riots in Wamena City, Papua Province (Prihandini, 2018).

The tragedy of the riots in Wamena City occurred on September 23, 2019, against the backdrop of the alleged racism of a teacher against a student (Ulfah \& Barry, 2019). Riris Panggabean, is a teacher of PGRI Wamena High School who allegedly uttered the word. The chronological event is when the teacher asks his student to read aloud, but a loud word is heard as an ape word at the hearing of one of the students. The issue spread quickly, causing the school to deftly find a way out, namely clarification between the two parties. The tail end of the issue, resulting in the outbreak of 
unrest on the 22nd and September 23, 2019. The casualties and damage to public facilities are the result of riots (Republika, September 24, 2019 edition).

The tragedy of the unrest reaped president Joko's response Widodo, who said the alleged racism was not true. He asserted that this was the spread of the issue, with the aim of provoking citizens. The call to be more thorough in receiving information was conveyed by the President, and the Government made efforts as early as possible, namely the evacuation of citizens (Kompas, 24 September 2019 edition).

The purpose of this paper is to look at the frame of the news formed by Republika Daily and Kompas, in presenting news related to the tragedy of the riots in Wamena City. The subjectivity of the media is not only on political news, but news of disasters and riots is also involved. Reconstruction and selection of issues is an important element of news. The weakness of the news with this kind of issue is the ideology of a certain group of people or elites or rulers, which exist in the society (Mallarangeng \& Tuijl, 2004).

The study used framing analysis techniques with models Zhongdan Pan and Gerald M. Kosicki. In this approach, framing analysis will be dissected based on four large structures, namely syntax, script, thematic, and rhetoric (Lotan, 2019). The four structures form a kind of theme that associates the semantic elements of a news narrative, in a global coherence (Alex, 2004). The source of the data used is news about the tragedy of the riots in Wamena City, Papua Province contained by Harian Republika and Kompas. The editions taken are 24, 28, and 30 September 2019 from the Daily Republika and 24, 28, and 29 September from Kompas.

Determination of editions taken based on news content that can be reviewed based on the side of the humanitarian crisis. All three editions of the news will be dissected based on four large structures, on framing analysis techniques with Zhongdan Pan and Kosicki models (Sintawati, 2019).

Research with journalism news studies, often found using framing analisi technique. In this case, researchers found three researches relevant to framing analysis of the tragedy of the riots in Wamena City, Papua Province. The first research was conducted by (Prihandini, 2018). The research was taken from the Journal of The Community with the title Of Humanitarian News Frame In Kompas Daily And Republika Against Refugees Rohingnya (Framing Analysis on Kompas News And Republika Edition September 6-11, 2017 Regarding Rohingnya Refugees) (Jati Kusuma, 2019). Apply qualitative research with documentation techniques as data collection. The focus of this research is the humanitarian crisis that is happening to rohingnya refugees. The paradigm used is constructivism, where it is known that the reality produced in the news is not singular but plural (Paramitha, 2020).

The second research was conducted by (Anjani, Irham, \& Waluyati, 2019). This research was taken from the Scientific Journal of Meaningful Communication with the title Of Media News Construction about the Islamic State of Indonesia (Framing Republika Analysis And Kompas). Apply descriptive qualitative research, with a framing analysis approach. The focus of this research is the construction of news related to the case of Islamic State of Indonesia by Harian Republika and Kompas. The difference between the construction of the two media, lies in how to compile facts and take on the source. Republika Daily takes official speakers from various groups of officials and countries, while Kompas completes the news with analysis and research.

The third research was conducted by Sintia Cahya Ningrum (Sintia Cahya Ningrum, 2019). The research was taken from the Journal of Communication Spectrum under the title Framing Analysis of The Death of Nurse Razan Najjar In BBC Indonesia Media And CNN Indonesia. The focus of the study was to examine the shooting of a Palestinian nurse named Razzan al-Najjar on BBC Indonesia and CNN Indonesia. Apply qualitative research methods, with zhongdang and kosicki model framing analysis techniques. The results of this study obtained that BBC Indonesia does not report the truth of the information has not been proven, while CNN Indonesia is quite detailed in explaining the problems and developments of the case. 
This analysis takes 3 news published by Republika Daily and 3 news from Kompas. News is a report or notification of an event or situation that is general and has just occurred submitted by journalists in the mass media (Djuraid, 2019).

The selection of facts in the news is based on the assumption of journalists, where in selecting facts contained two possibilities, namely what is chosen (included) and what is excluded. The construction of a fact refers to how facts ideas are expressed, as well as sentences and language styles used to the public (Eriyanto, 2011).

The general criterion of news value is a reference for journalists, in deciding the facts that deserve to be used as news. According to Brian S. Brook, George Kennedy, Darly R.Moen, and Don Ranly in News Reporting and Editing (1980:6-17) there are nine dimensions of news value, namely magnitude, newness, impact, actual (timeless), proximity, information, conflict, public figure, surprise, human interest, and sex (Hamid, Djohan, Admaja, Sanusi, \& Sumadiria, 2019).

The distinctive language of the media is based on the understanding/ideology of the newsmaker. Ideology according to Karl Marx (1818-1883) and Fredich Engels (1820-1895) was a fabrication or forgery used by a certain group of people to justify themselves. The concept of ideology based on the above understanding is very subjective, and its existence to legitimize the ruling class in the middle of society (Sobur, 2013).

It is acceptable that when the media articulates in a unified way the idea of how to understand reality, that understanding is presented through different types of messaging. Through this type of messaging, the media offers a way of looking at specific ethnic groups, cultures, women, leaders, or communities. The issue of ideology is how we look at the content or text of the media, and how the media publishes things that have, are, or will happen to a particular person (., 2013).

The ideology of the mass media is often attached to the political element. Politics is a matter of who acquires what, when, and how, it includes the division of values by the authorities of power and the holder of power, influence, and an action directed at maintaining or expanding another action. One of the purposes of the media is to form public opinion on various things, with the persuasive nature of the media and able to form public opinion, is the reason why the media is closely related to politics (Nimmo \& Perkins, 2018).

The facts presented to the news are the result of the construction of reality. The process of constructing reality is divided into three things, namely Externalization, Objectivity, and Internalization. Externalization is an attempt to pour or self-expression into the world, both in mental activity and physical activity (Luhuringbudi, Syamsuddin, \& Hakim, 2019). Then objectivity is the result of what has been achieved both mentally and physically from the results of human externalization activities. The last internalization, namely the re-absorption of the objective world into consciousness in such a way that subjective individuals are influenced by the structure of the social world (Burgin, 2012).

Language is a major element in the construction of reality. The language used by the media is verbal and non verbal. The function of language is not just to describe reality, but to determine the meaning of an image to a reality that will appear on the minds of the audience (Zhao, Chen, \& Zhao, 2020). Media understands various ways of influencing language and meaning, namely developing words and their associative meanings, expanding terms, replacing old meanings with new meanings, and establishing meaning conventions in language systems (Hamad, 2010).

\section{Theorotocal Framework}

The ideology of the mass media is often attached to the political element. Politics is a matter of who acquires what, when, and how, it includes the division of values by the authorities of power and the holder of power, influence, and an action directed at maintaining or expanding another action (Ulfah, Fajri, \& Fadillah, 2017). One of the purposes of the media is to form public opinion on various things, with the persuasive nature of the media and able to form public opinion, is the reason why the media is closely related to politics (Nimmo \& Perkins, 2018). 
The facts presented to the news are the result of the construction of reality. The process of constructing reality is divided into three things, namely Externalization, Objectivity, and Internalization. Externalization is an attempt to pour or self-expression into the world, both in mental activity and physical activity. Then objectivity is the result of what has been achieved both mentally and physically from the results of human externalization activities. The last internalization, namely the re-absorption of the objective world into consciousness in such a way that subjective individuals are influenced by the structure of the social world (Burgin, 2012).

Language is a major element in the construction of reality. The language used by the media is verbal and non verbal (Fadillah, 2019). The function of language is not just to describe reality, but to determine the meaning of an image to a reality that will appear on the minds of the audience. Media understands various ways of influencing language and meaning, namely developing words and their associative meanings, expanding terms, replacing old meanings with new meanings, and establishing meaning conventions in language systems (Hamad, 2010).

\section{Method}

This research includes qualitative research with a paradigm of constructivism. Qualitative approach is a research approach based on phenomenology and paradigm of constructivism in developing science (Muslim, 2016).

The data collection technique used is a documentation technique. Documentation techniques are done by studying documents and records that have a relationship with the analysis unit, so that it can be used to support data in research (Lexy J. Moleong, 2019). The data used is two types, namely primary and secondary data. The primary data on this study is the daily Republika newspaper edition 24, 28, 30 September 2019 and Kompas editions 24, 28, and 29 September 2019. As for secondary data is a reference that refers to books and journals. The three news editions will be analyzed using framing analysis with models of Zhongdang Pan and Gerald M. Kosicki.

\section{Results and Discussion}

Republika Daily News Frame Analysis

Frame
in Papua

Headline : President: Don't Be Repressive

Published Date : September 24, 2019

Syntax Structure

\section{Lead}

JAKARTA - President Joko Widodo (Jokowi) instructed the security forces not to take repressive measures in securing the actions that caused unrest in Papua. The Head of the Presidential Staff Office (KSP) Moeldoko said, the President asked all parties, including the security forces, to refrain.

\section{Background Information}

In addition, the President also ordered that efforts to resolve the unrest in the DistrictWamena, Jayawijaya Regency, is done in a proportionate and professional manner. This is so as not to cause the emotions of various parties so that unrest can be avoided.

\section{Excerpts, Sources, Statements}

Wamena, Jayawijaya Regency, is done in a proportionate and professional manner. This is so as not to cause the emotions of various parties so that unrest can be avoided.

- "There are no repressive commands. All are asked to refrain because this is very much to do with what is happening at the United Nations. So, do not we bring up a bad situation," said Moeldoko at the Presidential Palace Complex, Jakarta, Monday (23/9). The situation at the United 
Nations he was referring to was the movement of a number of Pacific nations that have charged Indonesia with human rights violations in Papua.

- Rioting again occurred in Papua simultaneously in Jayapura and Jayawijaya on Monday. In Wamena, action was carried out by local high school/vocational school students. They had been burning in a number of buildings in Wamena City, including the Jayawijaya Regent's Office, people's homes, and supermarkets.

- Dandim 1702/Wamena Lt. Col. Inf Chandra Diyanto revealed that the civilians who died in the riot reached 17 people. According to him, the civilians who died were from sharp object wounds and the victims of the fire. A total of 65 people were also injured and treated at Wamena Hospital

\section{Closing}

The number of deaths recorded yesterday adds to the length of the casualty list since the act of rejecting racism last month. At that time, during the unrest in Deiyai and Jayapura the government recorded four civilians and one TNI soldier died. Meanwhile, the local church recorded seven civilians dead in Deiyai and four in Jayapura.

This news frame explains the Government's claim that the unrest was not due to human rights violations in Papua. The issue of targeting Eastern Indonesians is attached to the element of racism, which is why the Government claims this in this frame. The government's focus on this frame is to address the issue proportionately and professionally.

In the script element, this frame deals with what, who, and why elements. What and why in this element discusses the picture of the case of the riot that occurred, which begins with the submission of the fact of the cause to the impact. Then the who element, the speech of important figures is conveyed in this frame, namely President Joko Widodo and the Chief of Staff office of the President (KSP) Moeldoko.

The thematic element in this frame is coherence. The coherence here is the inter-sentence intercession conveyed in the syntax structure, where facts are conveyed in a pointed and continuous manner based on the views of journalists.

Furthermore, the rhetorical element in this frame is the use of lexicon. Here's the sentence:

No repressive orders. All are asked to refrain because this is very much to do with what is happening at the United Nations. So, do not we bring up a bad situation," said Moeldoko at the Presidential Palace Complex, Jakarta, Monday (23/9). The situation at the United Nations is the movement of a number of Pacific nations that have charged Indonesia with human rights violations in Papua. In addition, the President also ordered that the efforts to resolve the unrest in Wamena District, Jayawijaya Regency, be carried out in a proportionate and professional manner. This is so as not to cause the emotions of various parties so that unrest can be avoided.

The use of repressive, proportionate, and professional words directed at the security apparatus, as if to say that the performance of the security forces in handling past cases, is not appropriate. The use of the word conveyed by important figures of the State, further clarifies the implied message of the word.

Frame : The Government Ensures Unrest Is Not Due to Human Rights Violations in Papua

Headline

: President: Don't Be Repressive

Published Date : September 24, 2019

Syntax Structure

\section{Lead}

JAYAWIJAYA - The wave of evacuation of residents from Wamena, Jayawijaya Regency, continued due to the unrest that occurred in the region on Monday (23/9). More than a thousand residents had left the area until Friday (9/27). 


\section{Background Information}

More than a hundred refugees from Wamena, since Friday afternoon arrived in Timika and temporarily occupied the refugee post at the Command Headquarters of the Air Force Base Yohannes Kapiyau Timika. Lanud Commander Yohanes Kapiyau Timika Lt. Col. Sugeng Sugiharto said on Friday morning as many as 187 refugees from Wamena boarded hercules air force planes arriving at Mozes Kilangin Timika Airport.

\section{Closing}

He hopes that The Seal of Transportation helps that residents do not have difficulty getting access out of Jayawijaya. "I think a decision for a civilian airline could help, especially those operating in Wamena," he said. According to Antara monitor, hundreds of residents crowded the Kargo Airport in Wamena. Some have been waiting three days for a turn. The people who want to evacuate consist of migrants and indigenous Papuans.

The script element in this frame is what and who that explains the cause of the evacuation problem, and the solution from the Government. Then, the thematic element in this frame is coherence. The form of coherence is delivered by the continuous delivery of facts. The facts are about the condition of the residents, the problems of the citizens, and the government's solution in the evacuation process.

Meanwhile, the rhetorical element in this frame is a sign. Here's the sentence: Police Chief Mimika AKBP Agung Marlianto said, it is not closed the possibility that the number of Wamena refugees arriving in Timika will increase. That is considering the nearest area from Wamena, namely to Timika or Sentani, Jayapura. The sentence above describes the phrase of a Police Chief who predicted the number of refugees would increase, although when he said it was a concern it had not happened. However, in the future based on that sentence, the number of refugees will increase due to regional factors.

\section{Frame}

\section{Headline}

Published Date

Syntax Structure

\section{: Government Aid Becomes The Next Problem For Wamena Refugees : Intervening Local Government \\ : September 30th, 2019}

\section{Lead}

JAYAWIJAYA - The condition of refugees from various regions in Wamena, Jayawijaya Regency, began to knock the hearts of regional heads from the region of origin of the refugees. Visits were carried out and assistance began to be distributed to refugees affected by the riots in Wamena on Monday (23/9) then

\section{Background Information}

The Ministry of Social Affairs last week said it had been working to distribute aid to refugees whose numbers reached

5,500 .

\begin{tabular}{l}
\hline Excerpts, Sources, Statements \\
• According to Nasrul, the funds from the \\
budget are not expected to be enough to help \\
all refugees. Therefore, he asked for overseas \\
assistance in other areas. "Hopefully the \\
central government will help as well," he said. \\
• Deputy for Law and Human Rights office \\
of the President's Staff, Jaleswari \\
Pramodhawardani, said the flow of exodus of \\
citizens from wamena is inevitable, \\
\hline
\end{tabular}




\begin{tabular}{l}
$\begin{array}{l}\text { referencing the latest developments in } \\
\text { Wamena }\end{array}$ \\
\hline
\end{tabular}

\section{Closing}

Jaleswari mentioned that the government will help the repatriation of migrants from Wamena. President Joko Widodo (Jokowi), said Dani, always prioritized the protection of indigenous Papuans (OAP) as well as migrants who were there. "The government facilitated them by providing Hercules," Jaleswari said yesterday.

The script element in this frame is why and how that explains the reasons and efforts made by the local government in the handling of existing cases. Next, the thematic element in this frame is coherence. The facts are prepared in a pointed way, and discuss the conditions of the refugees up to the expectations of the Local Government to the Central Government, related to assistance for Wamena refugees.

Kompas News Frame Analysis

Frame : Restraining Instructions for Law Enforcement Officers Not to Attract the Attention of Leaders of the U.N. General Assembly

Headline : Soldiers and police Asked Not to Be Lured

Published Date : : September 24th, 2019

Syntax Structure

\section{Lead}

JAYAPURA, KOMPAS - 16 people died and thousands displaced at army and police headquarters following anarchist protests in Wamena, Jayawijaya Regency, Papua. In Jayapura, four people marched after the rally, Monday (9/23/2019). Police and soldiers were asked not to be emotionally lured.

\section{Background Information}

The U.N. general assembly begins September 18, 2019, but a public debate session presenting the speeches of the country's leaders begins September 25. Whatever happens in Papua can attract the attention of the leaders of the UN General Assembly..

\begin{tabular}{l}
\hline Excerpts, Sources, Statements \\
In Jakarta, President Joko Widodo called \\
on law enforcement to refrain from the \\
situation after protests led to unrest in \\
Jayapura and Wamena, Papua. The public is \\
also expected to be easily hooked on issues \\
that are not necessarily true. \\
- Repressive measures are requested to be \\
avoided by law enforcement officers. "All are \\
asked to refrain because this has a lot to do \\
with what is happening at the UN," Moeldoko \\
said
\end{tabular}

\section{Closing}

The victim was evacuated to Bhayangkara Hospital, but did not survive. "The deceased gave his soul and body for a sense of security on the land of Papua," said Commander Kodam XVII/Cenderawasih Major General Herman Asaribab

The script element in this frame is who and how to explain the Government in responding to existing cases, with submissions around actions and efforts in case resolution. Furthermore, in the thematic element there is coherence. The submission of facts in a pointed way, starting with the explanation of the post-riot conditions, the response of the government, to the current condition of 
Wamena City after the riots. And lastly, the rhetorical element in this frame is the use of photo graphics. The photo describes the condition of the building after the riot, with photos of shops, offices and buildings in a state of fire.

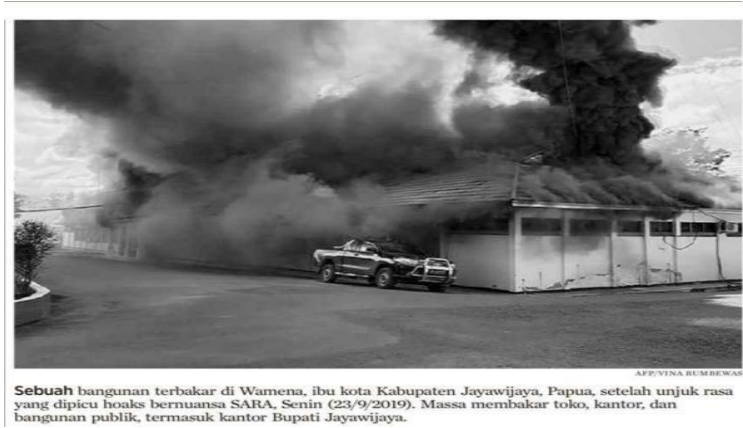

Figure 1. Kompas Newspaper September 24, 2019 Edition

Frame

Headline

Published Date

Syntax Structure
: Human Rights Commission Finds Humanitarian Crimes In Protests

: Wamena Exodus Continues

: September 28th, 2019

\section{Lead}

JAYAPURA, KOMPAS - The wave of migrants coming out of Wamena, Jayawijaya Regency, Papua, continues. As of Friday (9/27/2019), a total of 1,096 people arrived at Silas Papare air base, Jayapura, aboard the Air Force Hercules aircraft.

\section{Background Information}

Yesterday, the National Commission on Human Rights revealed the findings of its investigation into humanitarian crimes in the Wamena riots on Monday (23/9). Civilians, humanitarian workers such as doctors, and children were attacked and wounded to death

Excerpts, Sources, Statements
• Head of Papua Regional Human Rights
Representative Frits Ramandey said there was
a killing of doctors, intimidation of teachers,
and the burning of the bodies of three students
who refused to participate in the protests.
• Another finding, the riot rally was
planned on August 21-22, 2019, which
reinforced evidence of fuel oil to burn down
the facility. "Komnas HAM assesses planned
humanitarian crimes. We support the police
enforcing the law so as not to repeat it," he
said

\section{Closing}

Jayawijaya Police Chief Ajun Commissioner Tonny Ananda said the security situation in Wamena has been conducive. The death toll was 31 and 76 were injured. The Combined Health Team of the TNI was immediately sent to Wamena

The script element in this frame is what and who, which explains the findings of humanitarian crimes in the protests that led to the riots in Wamena City by the Head of the Papua Region Human Rights Representative. Furthermore, the thematic element in this frame is the nominalization of 
interkalisc, which is the word finding in a paragraph explaining about humanitarian crimes. Here's the sentence:

Yesterday, the National Commission on Human Rights revealed the findings of its investigation into humanitarian crimes in the Wamena riots on Monday (23/9). Civilians, humanitarian workers such as doctors, and children were attacked and wounded to death.

The rhetorical element in this frame is the graphic of the photo, which describes the condition of residents queuing to get off the plane supervised by security forces in the process of evacuating the residents.

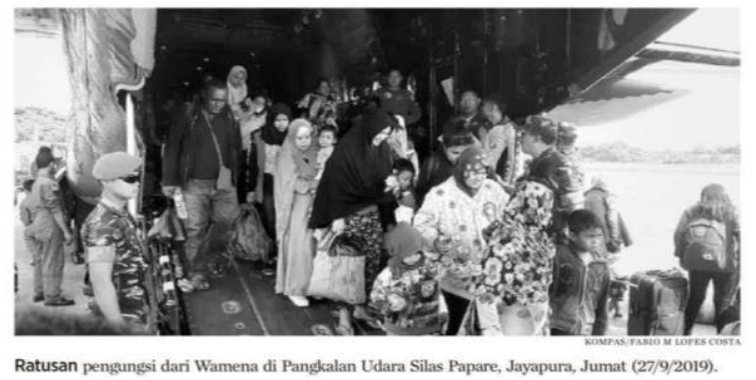

Figure 2. Kompas Newspaper September 28, 2019 Edition

\section{Frame : Human Rights Commission Finds Humanitarian Crimes In Protests Headline : Wamena Exodus Continues \\ Published Date : September 28th, 2019}

\begin{tabular}{c} 
Syntax Structure \\
\hline Lead \\
\hline
\end{tabular}

JAYAPURA, KOMPAS - The wave of migrants coming out of Wamena, Jayawijaya Regency, Papua, continues. As of Friday (9/27/2019), a total of 1,096 people arrived at Silas Papare air base, Jayapura, aboard the Air Force Hercules aircraft.

\section{Background Information}

Yesterday, the National Commission on Human Rights revealed the findings of its investigation into humanitarian crimes in the Wamena riots on Monday (23/9). Civilians, humanitarian workers such as doctors, and children were attacked and wounded to death

\begin{tabular}{l} 
Excerpts, Sources, Statements \\
\hline - Head of Papua Regional Human Rights \\
Representative Frits Ramandey said there was \\
a killing of doctors, intimidation of teachers, \\
and the burning of the bodies of three students \\
who refused to participate in the protests. \\
• Another finding, the riot rally was \\
planned on August $21-22$, 2019, which \\
reinforced evidence of fuel oil to burn down \\
the facility. "Komnas HAM assesses planned \\
humanitarian crimes. We support the police \\
enforcing the law so as not to repeat it," he \\
said
\end{tabular}

\section{Closing}

Jayawijaya Police Chief Ajun Commissioner Tonny Ananda said the security situation in Wamena has been conducive. The death toll was 31 and 76 were injured. The Combined Health Team of the TNI was immediately sent to Wamena 
The script element in this frame is what and who explains the terror during the exodus, the terror initiated by the Armed Criminal Group (KKB). Responses from some authorities were also delivered in this frame. Then, the thematic element found in this frame is coherence. Facts about the delivery of citizen conditions, solutions to the handling of terror problems by $\mathrm{KKB}$, and the response of the authorities are delivered in a retail and ongoing manner.

Stereotype is the way that every member of the group understands a social group (Islam, 2012 : 241). The stereotype formed by both media based on the first framing difference is to target the performance of the security apparatus in handling similar issues. Republika daily packed the framing by siding with Wamena refugees and the background to the unrest is not an issue of human rights violations. On the other hand, Kompas packed the background to the unrest by alluding to concerns about unprecedented human rights violations.

The second framing difference, the stereotype that the Republika Daily formed is to target on the side of community empathy. The packed facts conjure up the stereotype that ethnic minorities are often compromised by issues of racism and humanitarian crimes. Kompas formed stereotypes by suggesting that there was an anarchist side to the unrest, supported by the fact of the findings of humanitarian crimes by Komnas HAM.

Finally, the sterotip formed by Republika Daily is that there is a gap between the Central Government and the Local Government in terms of the distribution of aid. From the facts packed, the public will assume that the coordination between the Central and Local Governments has not been going as it should. Then, for Kompas the stereotype formed is to target the performance of the security apparatus in the handling of previous cases. This is supported by the fact that there was a terror attack by the Armed Criminal Group.

Prejudice is defined as the desire to give judgment to others, which is based on membership of one's social group (Murdianto, 2018). The study of the humanitarian crisis, framed by both media outlets, is based on racial prejudice based on the background of the riots. The facts presented by Republika daily and Kompas are deflected by the dish of how the security apparatus is performing in the handling of the case, then how to view both media in packing the humanitarian crisis that occurred, and followed by how the two media packed the problems that arose during the exodus process.

Discrimination is a negative treatment directed at a particular group, which is based on tribe, language, customs, religion, nationality, etc (Kuncoro, A, 2018). Framing the second packed media in the study of the humanitarian crisis, can be reviewed with discrimination of this type of racism. However, the facts presented do not contain any element of discrimination of this type of racism, but rather can be understood according to their respective insights. Therefore, the stereotypes, prejudices, and discriminations that formed in the beginning against ethnic minorities, can fade or even sharper.

Quoting from Internews (2014) the understanding of the humanitarian crisis is a situation where the condition of human suffering is at a high level, human well-being is in danger and covers a large scale (Rahardja, Moeins, \& Lutfiani, 2017). The humanitarian crisis in all three differences framing the two media, belongs to the complex emergencies category. The facts are packaged according to the understanding of the complex emergencies category which is the humanitarian crisis that occurs as a result of the conflict that led to the unrest.

Responsibility to protect is one solution for the country in the face of a humanitarian crisis. The facts presented in the three framing differences have shown how the Government's role in the handling of cases, namely the instruction for the security apparatus delivered directly by the President, then the provision of free transportation for the evacuation process of citizens, and the role of each Local Government in the distribution of assistance. 


\section{Conclusion}

The frame of the news by Republika Daily with a review of the humanitarian crisis shows its side to wamena refugees. The stereotypes and prejudices displayed by Republika give people an idea of opinion, that minorities are often subjected to the issue of racism and oppression, in the form of humanitarian crimes. While Kompas packaged the concept with the presentation of facts about terror attacks by armed criminal groups, from that fact there are stereotypes and prejudices for the public about the anarchist side of wamena in particular. This type of sterotype belongs to heterostereotype and prejudice in cognitive components. Then, in the discussion of this type of prejudice, the frame of this preaching can be reviewed with prejudice of this type of racial prejudice.

Republika daily and Kompas package the concept of discrimination in this frame of preaching with the dsikriminasi type of racism. The news frame of the two media agreed to package the concept by fostering opinion, as well as people's empathy towards ethnic minorities, as well as understanding the facts about terror attacks presented by Kompas, as a form of resistance and existence against discrimination that is often accepted.

The next concept is a humanitarian crisis and responsibility to protect. The frame of the news from both media has the same point of view, namely the humanitarian crisis that occurred starting from the conflict that led to the unrest. However, the two media agreed not to show the anarchist side of the perpetrators, given the stigma formed against Eastern Indonesian society. Republika daily and Kompas also present facts that correspond to the concept of responsibility to protect, namely conveyed about response to action from the Government in efforts to address humanitarian crimes that occur.

\section{Acknowledgment}

Assalamu'alaikum wr.wb. First of all, thank you for Allah that give me ease to finish this paper. Then, for my parents that always support and give me an advice, thank you for my brother too that always give me some help about finishing this paper. The last but not least, thank you for my lecture, Mr. Filosa Gita Sukmono that always guide me when I was did thesis, and give me a chance to join this conference.

\section{References}

- P. (2013). Media Komunitas dan Media Literacy. Jurnal ILMU KOMUNIKASI. https://doi.org/10.24002/jik.v4i2.225

Alex, S. (2004). Analisis teks media. Bandung: Penerbit Rosdakarya.

Anjani, H. D., Irham, I., \& Waluyati, L. R. (2019). Relationship of 7P Marketing Mix and Consumers' Loyalty in Traditional Markets. Agro Ekonomi. https://doi.org/10.22146/ae.36400

Burgin, M. (2012). Structural reality. In Structural Reality.

Djuraid, D. A. (2019). Jurnalisme Islam-Profesional dalam Pusaran Politik Identitas: Studi Kasus pada Harian Duta Masyarakat \& Harian Bangsa. Jurnal Komunikasi Islam. https://doi.org/10.15642/jki.2019.9.2.373-392

Eriyanto. (2011). Analisis Isi: Pengantar Metodologi untuk Penenlitian Ilmu Komunikasi dan ilmu-ilmu sosial lainnya. In Analisis Isi: Pengantar Metodologi untuk Penenlitian Ilmu Komunikasi dan ilmu-ilmu sosial lainnya.

Fadillah, D. (2019). DINAMIKA KOMUNIKASI ORGANISASI MUHAMMADIYAH DIY DAN PENCALONAN SENATOR DPD RI DALAM TINJAUAN TEORI KEPRIBADIAN KELOMPOK RAYMOND CATTELL. MEDIAKOM, 3(1), 1. https://doi.org/10.32528/mdk.v3i1.2409

Hamad, B. (2010). The antibiotics market. Nature Reviews Drug Discovery. https://doi.org/10.1038/nrd3267

Hamid, R., Djohan, G., Admaja, D. S., Sanusi, B., \& Sumadiria, H. (2019). Trafficking in border regions case study on violence against women and children victims of trafficking at the West Kalimantan Border. International Journal of Scientific and Technology Research. 
Jati Kusuma, M. I. (2019). Messages of parents affection for children in the movie bulan terbelah di langit amerika. International Journal of Communication and Society, 1(2), 89-96. https://doi.org/10.31763/ijcs.v1i2.47

Kuncoro, A, S. (2018). Metodologi Penelitian Manajemen. In penerbit Andi : Yogyakarta.

Lexy J. Moleong, D. M. A. (2019). Metodologi Penelitian Kualitatif (Edisi Revisi). PT. Remaja Rosda Karya. https://doi.org/10.1016/j.carbpol.2013.02.055

Lotan, F. F. (2019). Making a positive internet through Socmed Agawe Guyub. International Journal of Communication and Society, 1(1), 9-16. https://doi.org/10.31763/ijcs.v1i1.22

Luhuringbudi, T., Syamsuddin, M. D., \& Hakim, S. A. (2019). Activists communication dynamics for mobilization of minority politics in europe. International Journal of Communication and Society, 1(2), 4357. https://doi.org/10.31763/ijcs.v1i2.50

Mallarangeng, A., \& Tuijl, P. Van. (2004). Partnership for governance reform in Indonesia . Third World Quarterly. https://doi.org/10.1080/0143659042000232027

Murdianto. (2018). Stereotipe , Prasangka dan Resistensinya ( Studi Kasus pada Etnis Madura dan Tionghoa di Indonesia ). Qalamuna.

Muslim. (2016). Varian-Varian Paradigma, Pendekatan, Metode, dan Jenis Penelitian dalam Ilmu Komunikasi. Wahana.

Nimmo, J. R., \& Perkins, K. S. (2018). 2.6 Aggregate Stability and Size Distribution. https://doi.org/10.2136/sssabookser5.4.c14

Paramitha, A. (2020). Komunikasi efektif komunitas rumah baca dalam meningkatkan minat baca pada anakanak di dusun Kanoman. COMMICAST, 1(1), 1. https://doi.org/10.12928/commicast.v1i1.2408

Prihandini, W. (2018). The optimum level of tax compliance based on power of authority and trust in an antagonistic climate. European Research Studies Journal. https://doi.org/10.35808/ersj/954

Rahardja, U., Moeins, A., \& Lutfiani, N. (2017). Leadership, competency, working motivation and performance of high private education lecturer with institution accreditation B: Area kopertis IV Banten province. Man in India.

Sintawati, W. (2019). Computer mediated communication for construction-supported constructivism in communication and cultural learning. International Journal of Communication and Society, 1(1), 34-42. https://doi.org/http://dx.doi.org/10.31763/ijcs.v1i1.29

Sintia Cahya Ningrum. (2019). Analisis Framing Pemberitaan Tewasnya Perawat Razan Najjar di Media BBC Indonesia dan CNN Indonesia. Jurnal Spektrum Komunikasi. https://doi.org/10.37826/spektrum.v7i2.56

Sobur, A. (2013). an Industry. Alex Sobur.

Ulfah, M., \& Barry, A. (2019). Indonesia Leader Forum, post-truth and political interests in social media and television. International Journal of Communication and Society, 1(1), 17-25. https://doi.org/10.31763/ijcs.v1i1.18

Ulfah, M., Fajri, C., \& Fadillah, D. (2017). Pemahaman Literasi media Di Lingkungan Pengurus Pimpinan Wilayah Aisyiyah daerah Istimewa Yogyakarta Periode 2015-2020. Informasi, 47(2). https://doi.org/https://doi.org/10.21831/informasi.v47i2.16574

Zhao, J., Chen, C., \& Zhao, L. (2020). The spread characteristics of music videos relating to COVID-19 in China online video platforms. International Journal of Communication and Society, 2(1), 1-11. https://doi.org/10.31763/ijcs.v2i1.94 